\title{
Hubungan Pola Makan dan Pengetahuan Gizi Seimbang dengan Gizi Lebih Mahasiswa STIKes Mitra Keluarga
}

\author{
Cristin Octaviani Sagala, Noerfitri \\ Program Studi S1 Gizi, STIKes Mitra Keluarga
}

\begin{abstract}
Abstrak
Latar Belakang : Pada masa remaja diperlukan kebutuhan gizi yang berbeda dengan masa kanak-kanak. Pemenuhan kebutuhan gizi remaja dipengaruhi faktor seperti pola makan dan pengetahuan tentang gizi. Pola makan dan pengetahuan gizi yang tidak baik dapat mempengaruhi status gizi pada remaja. Prevalensi overweight pada remaja berdasarkan IMT/U pada 2018 naik menjadi 13,6\% dibandingkan tahun 2013 (11,5\%), sedangkan yang mengalami obesitas juga mengalami kenaikan dari tahun 2013 yaitu sebesar 14,8 menjadi 21,8\% pada tahun 2018. Studi ini ditujukan untuk menganalisis hubungan pola makan dan pengetahuan gizi seimbang dengan kejadian gizi lebih pada mahasiswa di STIKes Mitra Keluarga Bekasi.

Metode: Studi cross sectional dilakukan pada 161 mahasiswa STIKes Mitra Keluarga yang dipilih menggunakan teknik consecutive sampling. Instrumen yang digunakan yaitu kuesioner pengetahuan gizi seimbang dan Food Frequency Questionare (FFQ). Data dianalisis menggunakan uji Chi Square.

Hasil : Mayoritas sampel berjenis kelamin perempuan (94,4\%), berusia 19 tahun (50,3\%) dan berasal dari program studi S1 Keperawatan (43,5\%) dan analisis bivariat menggunakan uji Chi-Square menunjukkan bahwa nilai p-value pada masing-masing variabel penelitian yaitu Pola Makan (0,831) dan Pengetahuan Gizi Seimbang (0,952).

Kesimpulan: Tidak ada hubungan yang signifikan antara pola makan dan pengetahuan gizi seimbang dengan kejadian gizi lebih pada mahasiswa STIKes Mitra Keluarga Bekasi.
\end{abstract}

Kata kunci: Gizi lebih, Pengetahuan Gizi Seimbang, Pola Makan

\section{Diet and Balanced Nutrition Knowledge with Overnutrition of STIKes Mitra Keluarga Students}

\begin{abstract}
Background: In adolescence, different nutritional needs are needed from childhood. Nutritional needs of adolescents can influenced by factors such as diet and knowledge of nutrition. Poor diet and nutritional knowledge can affect the nutritional status of adolescents. The prevalence of overweight in adolescents based on BMI/age in 2018 increased to 13.6\% compared to 2013 (11.5\%), while those who are obese also experienced an increase from 2013, which 14.8 to $21.8 \%$ in 2018. This study aimed to analyze the relationship between diet and knowledge of balanced nutrition with the incidence of overnutrition among students at STIKes Mitra Keluarga Bekasi.

Methods: Cross sectional study was conducted on 161 STIKes Mitra Keluarga students who were selected using consecutive sampling technique. The instruments used were a balanced nutrition knowledge questionnaire and the Food Frequency Questionare (FFQ). Data were analyzed using the Chi Square test.

Results: Majority of the sample was female (94.4\%), 19 years old (50.3\%) and came undergraduate of Nursing program (43.5\%). Chi-Square test result indicated that the p-value for each research variable for diet was 0.831 and balanced nutrition knowledge was 0.952.

Conclusion: There was no significant relationship between diet and knowledge of balanced nutrition with the incidence of overnutrition among STIKes Mitra Keluarga Bekasi students.
\end{abstract}

Keywords: Balanced nutrition knowledge, Dietary pattern, overnutrition

Korespondensi: Cristin Octaviani Sagala

Email: cristinoctaviani6@gmail.com 


\section{PENDAHULUAN}

Remaja berada dalam masa transisi dari anak ke dewasa. Selain terjadi perubahan fisik, pada masa remaja juga akan terdapat perubahan emosional dan mental yang cepat. ${ }^{1}$ Remaja dengan usia 10-14 tahun akan tergolong dalam remaja awal, sementara itu 10-20 tahun akan tergolong dalam usia remaja akhir. ${ }^{2} \quad$ Remaja mengalami pertumbuhan yang cepat, sehingga kebutuhan gizi meningkat sehubungan dengan besarnya tubuh. ${ }^{3}$ Remaja membutuhkan zat gizi yang tinggi guna mendukung proses pertumbuhan dan perkembangannya yang sangat dipengaruhi oleh pengetahuan dan pola makan. Status gizi yang baik yaitu dalam kadar yang cukup. Permasalahan gizi pada remaja salah satunya ialah gizi lebih. Gizi lebih dapat terjadi akibat adanya ketidakseimbangan antara pemasukan dan pengeluaran energi. ${ }^{4}$

Prevalensi berat badan lebih pada usia $>18$ tahun menurut Indeks Massa Tubuh (IMT) tahun 2018 sebesar 13,6\%. Angka tersebut mengalami kenaikan dibandingkan tahun 2013 yang berjumlah 11,5\%, sedangkan yang mengalami obesitas juga mengalami kenaikan dari tahun 2013 yaitu sebesar 14,8 menjadi $21,8 \%$ ditahun 2018. ${ }^{5}$ Prevalensi gizi lebih pada remaja usia 16-18 tahun di Jawa Barat ialah sebesar 7,6\% dan pada usia $>18$ tahun sebesar 26,9\%, dengan prevalensi obesitas terbesar ke tujuh yaitu Kota Bekasi sebesar $34,03 \%$ dari total kasus di Jawa Barat sebesar $8.45 \%$. $^{6}$

Gizi lebih diakibatkan ketidakseimbangan asupan dan jumlah energi yang keluar. Kondisi tersebut bisa disebabkan adanya penyakit degeneratif. $^{7}$ Faktor yang menyebabkan gizi lebih pada remaja diantaranya ialah faktor genetik, psikologis, pengetahuan tentang gizi, aktivitas fisik, faktor lingkungan, konsumsi energi yang berlebih, jenis kelamin, socialekonomi, serta pendidikan orangtua. ${ }^{8}$

Pola makan kemungkinan asangat berpengaruh terhadap status gizi seseorang terutama jika dalam kondisi pola makan buruk. ${ }^{9}$ Pola makan yang baik dapat dilihat dari kuantitas dan kualiatas bahan pangan yang akan dikonsumsi. Hal ini dapat terjadi karena tingkat kesehatan individu dan masyarakat dapat dipengaruhi oleh konsumsi kuantitas dan kualitas makanan maupun minumannya. ${ }^{10}$ Selain pola makan tingkat pengetahuan gizi juga dapat mempengaruhi status gizi seseorang. ${ }^{11}$ Dalam hal ini khususnya adalah pengetahuan gizi seimbang. Hal-hal yang berhubungan dengan gizi sesuai dengan pedoman, serta prinsip gizi seimbang merupakan gambaran dari pengetahuan gizi seseorang. Hal ini disebabkan karena kurangnya informasi mengenai gizi. ${ }^{9}$ Pada penelitian Widjanarko \& Margawati menyatakan bahwa ada pengaruh dari pemberian edukasi gizi dengan peningkatan pengetahuan gizi serta perubahan nilai IMT pada remaja gizi lebih. ${ }^{12}$

Berdasarkan uraian, maka penting untuk diketahui hubungan antara pola makan dan pengetahuan gizi seimbang dengan kejadian gizi. Penelitian ini dilakukan pada mahasiswa/mahasiswi di STIKes. Penulis memilih lokasi STIKes Mitra Keluarga Bekasi sebagai lokasi penelitian dikarenakan STIKes Mitra Keluarga Bekasi merupakan perguruan tinggi dengan lokasi di daerah perkotaan. Mahasiswa/mahasiswi pada STIKES Mitra Keluarga memiliki kegiatan belajar dan kegiatan tambahan lainnya yang padat, sehingga peluang mahasiswa/ mahasiswinya untuk melakukan pola makan yang tidak seimbang akan meningkat, serta banyak makanan yang dijual di kantin maupun di luar perguruan tinggi juga memudahkan mahasiswa untuk mengkonsumsi kudapan tidak sehat, seperti makanan cepat saji dan makanan yang kurang higienis yang memungkinkan memicu kejadian gizi lebih.

\section{METODE}

Studi ini merupakan cross-sectional dengan pola makan dan pengetahuan gizi seimbang sebagai variabel independen, sedangkan gizi lebih dengan indikator IMT $\geq$ $23 \mathrm{~kg} / \mathrm{m}^{2}$ sebagai variabel dependen. Populasi studi ini yaitu 450 mahasiswa STIKes Mitra Keluarga Bekasi yang berusia 17 - 20 tahun, kecuali Program Studi S1 Gizi. Pengambilan data dilakukan pada bulan Juni-Juli 2020 dengan sampel sebanyak 161 responden yang dipilih secara consecutive sampling, sesuai kriteria penelitian sampai dengan kurun waktu tertentu hingga jumlah sampel terpenuhi. ${ }^{13}$ Kriteria inklusi yaitu usia $17-20$ tahun, Bersedia ikut serta dalam penelitian, mahasiswa STIKes Mitra Keluarga. Kriteria eksklusi yaitu mahasiswa STIKes Mitra Keluarga dengan status gizi kurang Program Studi S1 Gizi, tidak memiliki penyakit kronik dan akut, tidak menjalani diet khusus. 
Data primer yang dikumpulkan yaitu karakteristik yang terdiri dari jenis kelamin, usia dan program studi responden, pola makan dan pengetahuan gizi seimbang dengan menggunakan kuesioner yang terdiri dari 19 pertanyaan dengan tema 10 pesan gizi seimbang, data antropometri berat badan dan tinggi badan melalui pengukuran tidak langsung. Data antropometri didapatkan dari pengisian data pada kuesioner berupa google form. Indeks Massa Tubuh (IMT) didapatkan dari perhitungan rumus berat badan dalam $\mathrm{kg}$ dibagi tinggi badan dalam $\mathrm{m}^{2}$. Data tersebut dianalisis menggunakan uji chi-square.

Penelitian ini telah lolos kaji etik dari Komisi Etik Penelitian Universitas Muhammadiyah Prof. Dr. Hamka dengan nomor 03/20.04/0446.

\section{HASIL}

Berdasarkan Tabel 1, mayoritas usia responden dalam penelitian ini yaitu remaja akhir dengan usia 19 tahun sebanyak 50,3\%. Responden dengan jenis kelamin perempuan lebih besar daripada kelompok laki-laki. Persentase responden perempuan 94,4\%. Program studi responden dalam penelitian ini paling banyak yaitu S1 Keperawatan sebesar $43,5 \%$.

\section{Tabel 1. Karakteristik Responden}

\begin{tabular}{lcc}
\hline \multicolumn{1}{c}{ Variabel } & N & $\mathbf{\%}$ \\
\hline Usia (Tahun): & & \\
18 Tahun & 27 & 16,8 \\
19 Tahun & 81 & 50,3 \\
20 Tahun & 53 & 32,9 \\
\hline Jenis Kelamin: & & \\
Laki-laki & 9 & 5,6 \\
Perempuan & 152 & 94,4 \\
\hline Program Studi: & & \\
D3 Keperawatan & 5 & 3,1 \\
D3 TLM & 36 & 22,3 \\
S1 Keperawatan & 70 & 43,5 \\
S1 Farmasi & 50 & 31,1 \\
\hline \multicolumn{1}{c}{ TOTAL } & 161 & 100,0 \\
\hline
\end{tabular}

\section{Data Pola Makan dan Pengetahuan Gizi Seimbang}

Tabel 2 menunjukkan bahwa terdapat $50,3 \%$ responden dengan pola makan yang tergolong kurang dan 46,0\% responden dengan pengetahuan gizi seimbang yang tergolong kurang. Pengetahuan gizi seimbang yang dimaksud adalah pengetahuan tentang 10 pesan gizi seimbang yang terdapat dalam pedoman gizi seimbang. Sehingga, pola makan dan pengetahuan gizi seimbang mahasiswa STIKes Mitra Keluarga dapat digolongkan dalam kategori kurang. Hal ini berkaitan dengan kurangnya ilmu tentang 10 pesan gizi seimbang yang diberikan pada program studi selain gizi di STIKes Mitra Keluarga.

Tabel 2. Data Pola Makan dan Pengetahuan Gizi Seimbang

\begin{tabular}{lcc}
\hline \multicolumn{1}{c}{ Pola Makan } & N & \% \\
\hline Kurang & 81 & 50,3 \\
Cukup & 58 & 36,0 \\
Tinggi & 22 & 13,7 \\
\hline Pengetahuan Gizi & & \\
$\quad$ Seimbang & & \\
\hline Kurang & 74 & 46,0 \\
Cukup & 68 & 42,2 \\
Baik $\quad 19$ & 11,8 \\
\hline \multicolumn{1}{c}{ Total } & 161 & 100,0 \\
\hline
\end{tabular}

\section{Data Gizi Lebih}

Berdasarkan Tabel 3, hasil menunjukkan bahwa sebanyak $65,2 \%$ responden memiliki status gizi normal atau termasuk dalam kategori tidak gizi lebih, yaitu dengan nilai IMT $18,5-22,9 \mathrm{~kg} / \mathrm{m}^{2}$. Namun, masih terdapat $34,8 \%$ responden dengan status gizi lebih yaitu dengan nilai IMT $\geq 23$ menurut kategori asia. $^{14}$ Sehingga, status gizi mahasiswa STIKes Mitra Keluarga dapat digolongkan dalam kategori tidak gizi lebih atau memiliki status gizi normal.

Tabel 3. Gizi Lebih

\begin{tabular}{lcc}
\hline Gizi Lebih & $\mathbf{N}$ & $\mathbf{\%}$ \\
\hline Tidak & 105 & 65,2 \\
Ya & 56 & 34,8 \\
\hline \multicolumn{1}{c}{ Total } & $\mathbf{1 6 1}$ & $\mathbf{1 0 0 , 0}$ \\
\hline
\end{tabular}

\section{Pola Makan dengan Kejadian Gizi Lebih}

Berdasarkan Tabel 4, responden dengan status gizi normal cenderung memiliki pola makan dengan kategori tinggi dibandingkan responden dengan status gizi lebih. Namun, masih terdapat responden dengan status gizi 
normal yang miliki pola makan cukup sebanyak $67,2 \%$ dan pola makan kurang sebanyak $63,0 \%$. Sedangkan responden dengan status gizi lebih yang memiliki pola makan kurang sebanyak $37,0 \%$, cukup $32,8 \%$ dan tinggi sebanyak
31,8\%. Uji chi-square menunjukkan p-value $=$ 0,831 yang berarti tidak terdapat hubungan yang signifikan antara pola makan dengan kejadian gizi lebih.

Tabel 4. Hubungan Pola Makan dengan Kejadian Gizi Lebih pada Mahasiswa STIKes Mitra Keluarga Bekasi

\begin{tabular}{|c|c|c|c|c|c|c|c|c|}
\hline \multirow{3}{*}{$\begin{array}{c}\text { Pola } \\
\text { Makan }\end{array}$} & \multicolumn{4}{|c|}{ Gizi Lebih } & \multirow{2}{*}{\multicolumn{2}{|c|}{ Total }} & \multirow{3}{*}{$\begin{array}{c}\text { OR } \\
(95 \% \mathrm{CI})\end{array}$} & \multirow{3}{*}{$\begin{array}{c}p- \\
\text { value }\end{array}$} \\
\hline & \multicolumn{2}{|c|}{ Ya } & \multicolumn{2}{|c|}{ Tidak } & & & & \\
\hline & $\mathrm{N}$ & $\%$ & $\mathrm{~N}$ & $\%$ & $\mathrm{~N}$ & $\%$ & & \\
\hline Kurang & 30 & 37.0 & 51 & 63,0 & 81 & 100,0 & & \\
\hline Cukup & 19 & 32,8 & 39 & 67,2 & 58 & 100,0 & $1,264(0,461-3,460)$ & 831 \\
\hline Tinggi & 7 & 31,8 & 15 & 68,2 & 22 & 100,0 & $1,055(0,366-3,044)$ & 1,831 \\
\hline Total & 56 & 34,8 & 105 & 65,2 & 161 & 100,0 & & \\
\hline
\end{tabular}

*Uji chi-square, OR = Regresi Logistik

Tabel 5. Hubungan Pengetahuan Gizi Seimbang dengan Kejadian Gizi Lebih pada Mahasiswa STIKes Mitra Keluarga Bekasi

\begin{tabular}{|c|c|c|c|c|c|c|c|c|}
\hline \multirow{3}{*}{$\begin{array}{c}\text { Pengetahua } \\
\text { n Gizi } \\
\text { Seimbang }\end{array}$} & \multicolumn{4}{|c|}{ Gizi Lebih } & \multirow{2}{*}{\multicolumn{2}{|c|}{ Total }} & \multirow{3}{*}{$\begin{array}{c}\text { OR } \\
(95 \% \mathrm{CI})\end{array}$} & \multirow{3}{*}{$\begin{array}{c}p- \\
\text { value }\end{array}$} \\
\hline & \multicolumn{2}{|c|}{ Ya } & \multicolumn{2}{|c|}{ Tidak } & & & & \\
\hline & $\mathrm{N}$ & $\%$ & $\mathrm{~N}$ & $\%$ & $\mathrm{~N}$ & $\%$ & & \\
\hline Kurang & 26 & 35,1 & 48 & 64,9 & 74 & 100,0 & $1,155(0,391-$ & \\
\hline Cukup & 24 & 35,3 & 44 & 64,7 & 68 & 100,0 & $3,406)$ & \\
\hline Baik & 6 & 31,6 & 13 & 68,4 & 19 & 100,0 & $\begin{array}{c}1,167(0,390- \\
3,487)\end{array}$ & 0,952 \\
\hline Total & 56 & 34,8 & 105 & 65,2 & 161 & 100,0 & & \\
\hline
\end{tabular}

\section{Pengetahuan Gizi Seimbang dengan Kejadian Gizi Lebih}

Berdasarkan Tabel 5, responden dengan status gizi normal memiliki kecenderungan berpengetahuan gizi seimbang dengan kategori baik dibandingkan responden dengan status gizi lebih. Responden dengan status gizi normal yang memiliki pengetahuan gizi seimbang baik adalah sebanyak 68,4\%. Namun, masih terdapat responden dengan pengatahuan gizi seimbang kurang sebanyak 64,9\% dan cukup sebanyak $64,7 \%$. Sedangkan responden yang memiliki status gizi lebih cenderung memiliki pengetahuan gizi seimbang cukup sebanyak $35,3 \%$, kurang $35,1 \%$ dan baik sebanyak $31,6 \%$. Uji chi-square menghasilkan $p$-value $=0,952$ yang menunjukkan bahwa tidak ada hubungan yang signifikan antara pengetahuan gizi seimbang dengan kejadian gizi lebih.

\section{PEMBAHASAN}

\section{Pola Makan dengan Kejadian Gizi Lebih}

Pola makan merupakan suatu cara dalam mengatur jenis dan jumlah makanan yang dikonsumsi dengan tujuan tertentu. Pola makan dapat dilakukan dengan tujuan mempertahankan kesehatan, status gizi, serta untuk mencegah dan membantu kesembuhan penyakit. Penelitian menemukan tidak ada hubungan yang bermakna secara statistik antara pola makan dengan kejadian gizi lebih pada mahasiswa. Hasil menunjukkan bahwa mahasiswa dengan status gizi normal memiliki kecenderungan pola makan yang termasuk dalam kategori tinggi yaitu 
sebesar 68,2\% dibandingkan responden dengan status gizi lebih. Penelitian yang dilakukan oleh Putri juga menemukan tidak adanya hubungan antara pola makan dengan status gizi pada mahasiswa karena kebanyakan mahasiswa dengan status gizi normal memiliki pola makan yang kurang jika dibandingkan dengan mahasiswa dengan status gizi lebih dan kurus. Mayoritas penelitian melaporkan tidak ada hubungan antara pola makan dengan status gizi pada remaja seperti yang dilakukan oleh Noviyanti dan penelitian Matias et al. di Brazil.

Namun penelitian Cangöl Sögüt menyatakan sebaliknya bahwa pola makan pada remaja dapat mempengaruhi kejadian gizi lebih dan penelitian Mokolensang et al. juga menyatakan bahwa terdapat hubungan yang sangat signifikan antara pola makan yang dilihat dari asupan zat gizi terhadap gizi lebih. Sehingga dapat dikatakan bahwa salah satu faktor terjadinya gizi lebih disebabkan oleh pola makan.

\section{Pengetahuan Gizi Seimbang dengan Kejadian Gizi Lebih}

Pengetahuan gizi merupakan sebuah aspek kognitif yang dapat menggambarkan pemahaman sesorang terkait ilmu gizi dan jenis zat gizi, termasuk gambaran interaksinya terhadap status gizi. ${ }^{20}$ Konsumsi makanan akan sangat ditentukan oleh pengetahuan gizi. Pengetahuan terkait gizi seimbang, seperti 10 pesan gizi seimbang dalam Pedoman Gizi Seimbang akan tergambarkan dalam pengetahuan gizi. Uji chi-square penelitian ini menunjukkan tidak terdapat hubungan yang bermakna antara pengetahuan gizi seimbang dengan kejadian gizi lebih pada mahasiswa. Penelitian menunjukan bahwa mahasiswa dengan status gizi normal memiliki kecenderungan untuk berpengetahuan gizi yang baik, yaitu sebesar $68,4 \%$ dibandingkan mahasiswa dengan status gizi lebih. Hasil penelitian ini, sejalan dengan Liana et al. dalam penelitiannya pada mahasiswa yang menunjukkan bahwa secara signifikan tidak terdapat hubungan antara pengetahuan gizi seimbang dengan indeks massa tubuh. Penelitian Grace juga menyatakan hal serupa, tidak ada hubungan yang signifikan antara pengetahuan gizi dengan status gizi mahasiswa. Penelitian bin Shaziman et al. dengan responden remaja juga menunjukkan bahwa secara signifikan tidak ditemukan hubungan antara pengetahuan gizi dengan status gizi pada remaja.
Sichert-Hellert et al. dalam penelitiannya menunjukkan hal sebaliknya. Penelitian menunjukkan adanya hubungan yang signifikan antara pengetahuan gizi dengan status gizi pada remaja. Penelitian Cangöl Sögüt dan Dwi Jayanti \& Elsa Novananda juga menyatakan bahwa pengetahuan gizi mempengaruhi kejadian gizi lebih pada remaja. Maka dari itu, dapat dikatakan bahwa pengetahuan gizi khususnya pengetahuan akan gizi seimbang merupakan salah satu faktor yang dapat menyebabkan terjadinya gizi lebih.

Adapun keterbatasan penelitian ini yaitu pengambilan data tidak secara langsung (melalui google form), karena penelitian ini dilakukan ketika pandemi Covid-19 sedang terjadi sehingga untuk pengambilan data antropometri tidak dapat dilakukan secara langsung agar tetap mengikuti protokol kesehatan yang sedang berlaku dan para responden diberikan arahan untuk mengukur secara mandiri dengan memberikan arahan dan pedoman pengukuran antropometri dalam bentuk pdf, risiko ketidakakuratan data mungkin terjadi selama pengukuran. Penggunaan $F F Q$ secara online tanpa adanya food recall yang menyebabkan hasil penelitian tidak signifikan.

\section{KESIMPULAN}

Tidak terdapat hubungan antara pola makan dan pengetahuan gizi seimbang dengan kejadian gizi lebih pada mahasiswa STIKes Mitra Keluarga Bekasi. Sebaiknya dilakukan edukasi mengenai pengetahuan gizi seimbang kepada seluruh mahasiswa STIKes Mitra Keluarga Bekasi.

\section{DAFTAR RUJUKAN}

1. Adriani M, Wijatmadi B. Pengantar Gizi Masyarakat. Jakarta: Prenadamedia Group; 2014.

2. Kemenkes RI. Penilaian Status Gizi. Jakarta: Kementerian Kesehatan Republik Indonesia; 2017. 315 p.

3. Maita L, Saputri EM, Husanah E. Gizi Kesehatan Pada Masa Reproduksi. 1st ed. Yogkyakarta: Budi Utama; 2019.

4. Simanungkalit SF. Determinan Gizi Lebih pada Remaja di SMP YPI Bintaro Jakarta. J Ilmu Kesehat Masy. 2019;8(01):25-9.

5. Kemenkes RI. Hasil Utama Riset Kesehatan Dasar Tahun 2018. Kementrian Kesehat Republik Indones. 2018;1-100. 
6. Dinas Kesehatan. Dinas Kesehatan Jawa Barat: Profil Kesehatan. Jawa barat; 2016.

7. Almatsier S. Prinsip Dasar Ilmu Gizi. 1st ed. Jakarta: Gramedia Pustaka Utama; 2009.

8. Nur AS. Faktor Risiko Yang Berhubungan Dengan Kejadian Gizi Lebih Pada Remaja Di Perkotaan. Unnes J Public Heal. 2013;2(1):2-5.

9. $\mathrm{Mu} \mathrm{M}, \mathrm{Xu} \mathrm{L}, \mathrm{Hu} \mathrm{D}, \mathrm{Wu}$ J, Bai M. Dietary Patterns and Overweight / Obesity: A Review Article. 2017;46(7):869-76.

10. Depkes R. Pedoman Gizi Seimbang. Jakarta; 2014.

11. Grace FA. Hubungan Pengetahuan Gizi Dengan Status Gizi Pada Mahasiswa TPB Sekolah Bisnis Dan Manajemen Institut Teknologi Bandung. Skripsi. 2017;1-133.

12. Widjanarko B, Margawati A. Pengaruh intervensi pendidikan gizi terhadap peningkatan pengetahuan gizi, perubahan asupan zat gizi dan indeks massa tubuh remaja kelebihan berat badan. J Gizi Indones. 2015;4(1):38-47.

13. Hidayat A. Metode Penelitian Keperawatan dan Tekhnik. Jakarta: Salemba Medika; 2009.

14. International Obesity TaskForce. The Asia-Pasific Perspective: Redefining obesity and its treatment. 2000.

15. Putri GP. Hubungan Citra Tubuh (Body Image) dan Pola Konsumsi dengan Status Gizi Mahasiswi Tingkat I Jurusan Gizi Poltekkes Kemenkes Padang Tahun 2014. 2014;(hal 140).

16. Noviyanti $R$ dewi \& MD. Hubungan Pengetahuan Gizi, Aktivitas Fisk, dan Pola Makan terhadap Status Gizi Remaja di Kelurahan Purwosari Laweyan Surakarta. Univ Res Colloq Univ Muhammadiyah Magelang. 2017;421-6.

17. Matias MG, Fernando, Jucemar, Guedes
F de A. Association between Screen Time and Dietary Patterns and Overweight/Obesity among Adolescents. Rev Nutr. 2017;30(3):377-89.

18. Cangöl Sögüt S. Determining the differences in nutrition knowledge, dietary behaviors, physical activity and self-efficacy behaviors based on obesity status among adolescents. J Hum Sci. 2018;15(2):747.

19. Mokolensang OG, Manampiring AE, Fatimawali. Hubungan Pola Makan dan Obesitas pada Remaja di Kota Bitung. J e-Biomedik. 2016;4(1):128-35.

20. Khomsan A. Teknik Pengukuran Pengetahuan Gizi. Bogor: Departemen GMSK Fakultas Pertanian IPB; 2000.

21. Liana AE, Soharno, Panjaitan AA. Hubungan antara Pengetahuan Gizi Seimbang dengan Indeks Massa Tubuh Pada Mahasiswa. J Kebidanan. 2017;7(2):132-9.

22. bin Shaziman S, Rani MDM, Aripin KN bin N, Hamid NA, Sulaiman WNW, Rahman ZA, et al. Assessing nutritional knowledge, attitudes and practices and body mass index of adolescent residents of orphanage institutions in Selangor and Malacca. Pakistan J Nutr. 2017;16(6):406-11.

23. Sichert-Hellert W, Beghin L, De Henauw S, Grammatikaki E, Hallström L, Manios $\mathrm{Y}$, et al. Nutritional knowledge in European adolescents: Results from the HELENA (Healthy Lifestyle in Europe by Nutrition in Adolescence) study. Public Health Nutr. 2011;14(12):208391.

24. Dwi Jayanti $\mathrm{Y}$, Elsa Novananda $\mathrm{N}$. Hubungan Pengetahuan Tentang Gizi Seimbang Dengan Status Gizi Pada Remaja Putri Kelas XI Akuntansi 2 di SMK PGRI II Kota Kediri. J Kebidanan. 2019;6(2):100-8. 